\title{
On Integrating the Spirit of Volunteer Teaching in Western China into Higher Physical Education
}

\author{
Haizhe Zhang1, Minghui $\mathrm{Wu}^{2}$, Ke Tang1 \\ ${ }^{1}$ College of Physical Education, Baoding University, Baoding, China \\ ${ }^{2}$ Yanyang Middle School, Dingzhou, China \\ Email: zhz121100@163.com
}

How to cite this paper: Zhang, H. Z., Wu, M. H., \& Tang, K. (2021). On Integrating the Spirit of Volunteer Teaching in Western China into Higher Physical Education. Advances in Physical Education, 11, 415-423. https://doi.org/10.4236/ape.2021.114034

Received: September 1, 2021

Accepted: November 12, 2021

Published: November 15, 2021

Copyright $\odot 2021$ by author(s) and Scientific Research Publishing Inc. This work is licensed under the Creative Commons Attribution International License (CC BY 4.0).

http://creativecommons.org/licenses/by/4.0/

\begin{abstract}
The spirit of Volunteer teaching in Western China is the embodiment of patriotism. Based on literature review, this paper explores its spiritual connotation and value of the times, summarizes the necessity and way of introducing the spirit to higher physical education. The moral education of physical education courses needs to be promoted through a good integration of the spirit of volunteering to teach in the west into physical education, thereby more talents of service-oriented and high-quality can be cultivated in colleges and universities.
\end{abstract}

\section{Keywords}

Spirit of Volunteer Teaching in Western Region, Institutions of Higher Learning, Physical Education, Integration

\section{Introduction}

Volunteer teaching in the west refers to the behavior that college students take advantage of their summer and winter vacations, or internships before graduation to support education in poor area of the west, or graduating college students directly participate in the national support for education in Western China, that is, to the west, to basic level units, to the places where our nation needs them the most (Deng, 2015). Early in 2007, the Ministry of Education promulgated the Opinions on Vigorously Promoting the Work of Supporting Teaching in the Internship of Normal Students. It pointed that college students' volunteer teaching in the west plays an important role in promoting education equity, changing the 
lagging status of education in the west, and reducing the education gap between the east and the west. Due to the special national conditions that the development of the east and the west of China is unbalanced, the volunteer teaching activity in the west has become a volunteer activity with Chinese characteristics. It has gradually become a practical choice for many college students to make the best of their talent advantages and carry the volunteer spirit to new heights.

If sports are strong, China will be strong and national sports will flourish. The Sports Volunteer Service Project will establish and improve a service organization system of a national fitness volunteer, and expand the participation of athletes and coaches. The number of volunteers will include volunteer service into the assessment of physical education students and teachers, which encourages sports majors and outstanding athletes to go to underdeveloped areas for voluntary activities.

\section{The Connotation of Volunteer Teaching Spirit in Western China}

The program Teachers Talk, a large-scale public moral course commissioned by China Education Television, aired a television special in which the story of Baoding University graduates voluntary work in the west was shown and the spirit of serving the people and contributing to the motherland was demonstrated. Hou Chaoru, Li Guizhi and Wei Zhiying, representatives of graduates volunteering to teach in the west, introduced their work and life in Xinjiang and Tibet through an interactive link, and expressed their firm determination to devote themselves to the cause of education and serving the people in the west. The program demonstrated the spirit and vivid stories of the western volunteer teaching graduates. Taking root at the grassroots level, sticking to their ideals, uniting the nation, dedicating themselves selflessly, they lighted up the dreams of children in the west with their youth, and explained the connotation and value of the western volunteer teaching spirit.

\subsection{Spirits of Strengthening Their Conviction, Being Loyal to the Party and Struggling for the Education}

Ideals and convictions are the spiritual pillar and political soul of Chinese Communists. Only with firm ideals and convictions can we stand the test, go steadily and go for a long time. It was the strength of this belief that enabled the Chinese Communist Party to leave their hometown and join the west without any preferential treatment. In response to the call of the Party, Zhang Guimei came to Yunnan from Heilongjiang province to support the construction of the border area. Rooted in poverty-stricken areas for more than 40 years, she devoted herself to teaching in the poor mountainous areas of southwest China.

\subsection{Spirits of Loving Their Country, Shouldering Mission and Dedicating Themselves}

Patriotism is a noble feeling, but it is also a sense of responsibility. General Sec- 
retary Xi Jinping stressed, "Chinese intellectuals have always had a strong devotion to family and country and a strong sense of social responsibility. They have always attached importance to morality and obligation, and shouldered great responsibility. Generation after generation of intellectuals have contributed their wisdom and strength to China's revolution, construction and reform." (Qiu, 2018). Five retired teachers from Nankai University actively responded to the Ministry of Education's plan to support Western China and went to Kashgar University to carry out volunteer teaching. They bravely undertake the mission of educating people for the Party and for the country. They dedicate themselves to the western regions selflessly and demonstrate that the needs of the Party, the country and the people are their own missions.

\subsection{Spirits of Taking Root at the Grassroots Level, Making Greats Effort and Sticking to the Faith}

In 2014, General Secretary Xi Jinping wrote back to the representatives of the graduates supporting education of Western China from Baoding University, Hebei, to encourage them, "Good youngsters are ambitious in all directions, and aspirants struggle without regret. I hope that more and more young people will follow your example and make contributions to the grassroots and the people. Let the flowers of youth bloom where it is most needed in the country, and write a particularly wonderful story of your life in the great practice of realizing China Dream." (Xi, 2014). Although conditions in the west are harsh, those graduates who have taken root in Xinjiang will spend a lifetime accomplishing their missions to fulfill their promises. It is precisely this spirit that has enabled them to take root in the border areas for twenty years and contribute silently to the local basic education and national unity. The initiative of volunteer teaching in the west from Baoding University is indeed the reflection of contemporary youth's faith and a demonstration and guidance for young people.

\section{The Value of the Times of Volunteer Teaching in the West}

\subsection{Meet the National Requirements for the Training of Contemporary Sports Majors}

The construction of a strong sports country is inseparable from the broad masses of sports staff. Physical education in colleges and universities is the cradle of future sports builders and successors. College students in the new era should deepen their understanding of socialism and take the initiative to undertake the historical mission of realizing the great rejuvenation of the Chinese nation. Supporting education in Western China can cultivate physical college students' voluntary spirit, which can, to some extent, promote the construction of socialist spiritual civilization and the development of voluntary service. The deeds and spirit of Baoding University's volunteer groups in Western China have exerted a lasting and significance influence on young people throughout the country. They are loyal to the Party, patriotic and dedicated, and stick to the frontier and serve the grassroots 
level, which is a good value guidance for young people in many aspects.

\subsection{Promoting Physical Educational Development in the Western Region}

In 2011, the State General Administration of Sport started the activities of sending teachers to the west. According to the requirements of the Youth Department of the State General Administration of Sport, Tibet and Xinjiang hold a training course for sending teachers to the west every year, aiming to accelerate the training of sports reserve talents and promote the comprehensive quality of coaches and physical education teachers in the western region.

Since the 18th National Congress of the Communist Party of China, more and more college students have rushed to the western regions to take root at the grassroots level. Imparting knowledge and educating people in the west, they have written a chapter of their life with which passions and struggles are filled to bring endless vitality to the vast land, to bring hope to students in remote areas. General Secretary Xi Jinping has stressed many times that "poverty alleviation requires rich pockets as well as rich brains". Guided by the concept of "poverty alleviation requires nurturing wisdom", he advocates "education equity promotes social equity and justice" to achieve the goal of "blocking the intergenerational transmission of poverty". Through volunteer teaching activities, college students can have a deep understanding of the current situation and problems of education in the west, which make them think and do the research, and then contribute to the development of Western China. Their participation injects educational power into the west, making up for the shortage of the teachers in western regions to a certain extent. They are "nurturing" wisdom from aspects of educational concepts, educational methods and teaching means. Physical education majors in can deeply understand the status quo of physical education in the western region through volunteer teaching activities, and stimulate thinking and research. The participation of college student volunteers has injected the strength of physical education into the western region, and to a certain extent made up for the lack of physical education teachers in the western region, and truly implemented the "support" wisdom in terms of educational concepts, methods, and teaching methods. Wang Jianchao, a graduate from the Department of Physical Education of Baoding University, a member of the first group of physical education students to take root in the west, has been sticking to Xinjiang for 20 years, and has made contributions to promoting the development of physical education in the western region.

\subsection{Promoting the Self-Improvement and Development of College Students}

College is the best time for the youth to establish a correct outlook on life, world outlook and values. It is also a good time to serve the motherland, go to the west and to the grassroots, and make great contributions and accomplish great tasks to the places where they are needed the most. Supporting teaching in the west 
can not only win social recognition, but also demonstrate the youth's enthusiasm and responsibility. Everyone needs to steel themselves, thereby enriching their life and increasing their social knowledge. It is easier for people with rich experience to establish themselves in society. The same is true for college student volunteers. By participating in volunteer teaching services, they can exercise themselves and increase experience. They can acquire new knowledge and practice new knowledge, and improve skills. Also, by the services, they can seek psychological growth and development. They can enhance self-confidence and experience a sense of self-worth.

\section{The Necessity of Introducing Western Volunteer Teaching Spirit into College Physical Education}

\subsection{The Need of Physical Students' Growth and Development}

In the era of economic globalization and information opening, great changes have taken place in people's way of life and thoughts. The pluralistic thought has a certain effect on college students' ideas. Modern college students have a positive desire, but they are lack of confidence and perseverance. Besides, many problems such as lack of ideal and faith and distortion of value orientation have been reflected among college students on account of pursuing material enjoyment too much, ignoring cultivation of moral and ability, lacking the spirit of arduous struggle, coupled with the impact of "money worship" "hedonism" and "self-interest". Most of the students majoring in physical education have an extraverted personality with strong self-awareness, and have obvious bipolar psychology affected by professional characteristics. The cultural accomplishments of physical education majors are lower than those of other majors. Therefore, their performance is different from other majors in theoretical level, ethical standards, and living standards. The spirit of supporting teaching in the west embodies the patriotic sentiment of the youth, that is "Good children are ready to offer their services wherever they are needed, and there is no regret for people who have a will to struggle". It accords with the requirements of the times and the needs of the people. It is the most silent example power for college students. They should learn from the spirits of volunteer teaching group in the west, taking root at the grassroots level; dedicating selflessly; sticking to their ideals; loving their country and people ardently; assuming the responsibility. At any moment, students should develop a positive attitude and clear their position, and keep hardheaded in study and work. Colleges and universities are places to train the successors of socialism. They should strengthen the cultivation of students' outlook on life and values, so they should employ various ways to carry forward and inherit the spirit of volunteer teaching in western China.

\subsection{Promoting the Moral Education of PE Course in Higher Education}

Colleges and universities which shoulder the responsibility of the youth growing 
up, are bases of cultivating high-skilled and high-quality talents. Guidelines of the Institutions of Higher Learning Education Course Construction pointed out that "physical education courses should set up a concept that health comes first". Besides, it should attach importance to education in patriotism and traditional culture. Furthermore, they should develop students' indomitable quality and instill a sense of responsibility. Physical education in the institutions of higher learning has the natural advantage of launching the moral education system of PE curriculum. In the Outline of Building a Powerful Country in Sports, it is clearly proposed that we should vigorously promote the Chinese sportsmanship. We can comprehensively promote the moral education system in colleges and universities, exploring the Chinese sportsmanship and integrating it into the construction of socialist core value system. The spirit of supporting education in Western China is the carrier of moral education of physical education in the institutions (Wang, 2018). The connotation of the spirit of supporting education in the west: taking root at the grassroots level; dedicating selflessly; loving their country and people ardently; assuming the responsibility, will have a certain infiltration effect on students' behaviors and values. The spirits should be integrated into PE courses to arouse students to carry out thorough study and thinking. The whole volunteer groups and every volunteer will not only stimulate students' enthusiasm for taking root in the grassroots, struggling hard amid difficulties and grasping the nettle, but also cultivate students' strong patriotic feelings.

\subsection{Imparting and Inheriting the Spirit of Supporting Education in Western China}

In each period of China's reform and construction, a new national spirit will emerge, whether it is the "Daqing Spirit", "Flood fighting spirit", "fighting against SARS spirit", etc., which are the continuation and distillation of the Chinese nation's struggling hard amid difficulties (Li, 2007). Its connotation and foundation are pure patriotism. Contemporary college students are the future of the motherland and the hope of the nation. Whether they have excellent national spirit is significantly related to the great rejuvenation of the Chinese nation. Therefore, it is necessary to strengthen their national spirit education, and train students to be brave in shouldering responsibilities, and to develop the sense of duty to strive (Yin \& Zheng, 2004). They should be noble-minded and sound. And they have confident personalities with inflexible will. They should be cultivated into qualitied builders of the cause of socialism with Chinese characteristics. The spirit of volunteer teaching in the west has strong moral characteristics, which can lead college students to be virtuous, and it is a beneficial supplement to the moral education in colleges and universities. In order to realize Chinese Dream of the great rejuvenation of the Chinese nation, institutions should take the spirit seriously as an example for college students. The connotation of the spirit and its rich value of the times should be refined seriously. Besides, students should be trained to have the correct ideals and beliefs and the spirit of strug- 
gling hard amid difficulties, and enhance patriotism, so that they become a new generation of people with capability and responsibility.

\section{The Way of Introducing the Spirit of Volunteer Teaching in the West into Higher Physical Education}

\subsection{Guidance of Curriculum Objectives}

The core content of PE education in the institutions in the new era is patriotism, and the spirit of supporting education in Western China is the most direct embodiment of patriotism. As the basic channel for the supply of physical education teachers in China, the major itself in the institutions shoulders the important task of training and bringing up professional athletic talents in the new era. For this reason, it should be based on the needs of national strategy and people's well-being, and serve the needs of national and social development. The basic task of strengthening moral education and cultivating people is to put moral education first, to embed the spirit elements into the teaching objectives of physical education and then realize the integration of knowledge and skills, theory and practice, emotional attitude and values, and gradually and naturally achieve the goal. Loyalty to the Party's education, a firm political stand, correct values, a high degree of professional responsibility and a sense of social responsibility are teachers' professional ethics. Students in the PE class can learn sports skills, at the same time, their patriotism, selfless dedication, brave spirit of undertaking missions can be enhanced, and the depth and breadth of the curriculum can be enriched. The guidance of spirit of volunteer teaching in Western China helps students to set up right life goals, comprehensively understand the world, appropriately guide their career planning, and lay a good foundation for their future development. It is also an interpretation and manifestation of teachers' professional ethics and education.

\subsection{Integrating Cases into Theory Courses and Activating Learning Enthusiasm}

In order to make each student learn, understand and consciously practice the spirit of volunteer teaching in the west, and ask them to learn from examples, advocate examples to form inheritance and relay effect, teachers in theory courses of college physical education specialty should make full use of new media technology and integrate physical education network resources to provide students with true-life teaching cases related to the spirit. Teachers can introduce the true story of volunteer teaching in Western China to students in combination with the characteristics of sports projects, so that students can understand that they need to be proactive and innovative in their career development stage. Teachers can also carry out some practical classroom teaching activities with the spirit of volunteer teaching as the core. For example, they can organize students to watch the program Teachers Talk which is an open moral education course made by CCTV and ask students to write their reviews. In addition, they can organize 
and carry out thematic teaching activities such as speech contests or debate contests related to the spirit. Integrating volunteer teaching in Western China with professional ideals, these activities can arouse students' emotional resonance, and infect them in an imperceptible way. In this way, students can truly "internalize the spirit and externalize in their actions".

\subsection{Infiltrating the Spirit into Process of Skill Teaching Class}

The spiritual value of volunteer teaching spirit in Western China in the new era is being patriotic, dedicated, hard-working and enterprising. Physical education itself is a good material for patriotic education. Therefore, teachers can take advantage of sports celebrities which students are familiar with to mobilize the enthusiasm of students to exercise. For example, teachers can tell some hard-training stories of our nation's excellent athletic talents, as well as their results to the students. The spirit and temperament of a professional athlete can be seen from them. The spirit of perseverance, selfless dedication, bravery, unity and pursuit of excellence is integrated with the spirit of supporting teaching in Western China, guiding students to form a good professional quality, and making clear the responsibility of becoming a physical education teacher after graduation. In the process of skill teaching, teachers can infiltrate the spirit of western volunteer teaching into the teaching methods according to the characteristics of each project. For example, in high-intensity track and field courses, students can not only learn sports skills, but also exercise their strong will and ability to innovate. The pursuit of excellence is the inherent requirement of sportsmanship. And the connotation of contemporary sportsmanship includes never giving up, tenacious struggle, unity and cooperation, and so on, which is completely consistent with the spirit of volunteer teaching in Western China. In the class of ball games, students can be divided into groups for practice by taking advantage of the characteristics of team sports such as volleyball, basketball and football. The teaching form will cultivate students' collective spirit. Students can also be organized for group competition to overcome the tension and fear of the competition, and to improve their ability of psychological quality in the face of difficulties as well. No matter what kind of teaching methods and means are adopted, students can not only master professional knowledge, but also take root their ideals and beliefs, feelings of family and country and sense of social responsibility.

\subsection{Integrating the Volunteer Teaching in the West into Internship to Expand Teaching Space}

The development of sports in Western China is relatively behind, and it is urgent to improve the level of physical education to promote favorable development of the areas. As an important part of college teaching system, practice can test the whole teaching quality comprehensively. The internship can build a bridge between school and society to inject fresh strength into sports teachers in Western China. It is a great opportunity to demonstrate students' responsibility, convey 
hope, gather strength, cultivate students' sense of social responsibility and improve their professional quality. When students walk into the west, they can understand the current situation of physical education in the west and recognize the hardships and difficulties of physical education teaching there. They can also experience the sour, sweet, bitter and hot of physical education teachers in the west, and experience the happiness of success and sharpen their spirit and will. In the practice, students can practice skills and complete the tasks of the internship. Learning something and making great contributions and accomplishing great tasks in the vast world of western China, they can realize their self-growth and improve the development of physical education in the western region to achieve a win-win situation.

\section{Conclusion}

The spirit of volunteer teaching in Western China is a spirit of volunteer service. It is hoped that more college students will pass on the spirit of volunteer teaching in Western China and devote their light and heat to the land of Western China. The integration of the spirit of supporting education in the west and physical education in colleges and universities is helpful to cultivate students' spirit of arduous struggle, indomitable struggle and physical courage, and plays an important role in the construction of sports power and training of service talents in institutions of higher learning.

\section{Conflicts of Interest}

The authors declare no conflicts of interest regarding the publication of this paper.

\section{References}

Deng, W. S. (2015). Volunteer Teaching with "Sympathy" Alone Can Not Meet the Expectation of Fairness. Visual Field of Education, 16-17.

Li, R. (2007). Promoting the National Spirit and Advancing the Construction of Socialist Core Values. Science and Technology of Western China, 49-50+55.

Qiu, Y. (2018). Volunteering and Undertaking Missions of the Times. Journal of Political Work, 1.

Wang, Q. Y. (2018). The Significance of Carrying forward Chinese Sports Spirit to Cultivating Socialist Core Values of Contemporary College Students. Xuchang University Journal, 37, 90-93.

Xi, J. P. (2014). Message to the Youth: The Button of Life Must Be Fastened at the Beginning. Guizhou Legal Science, 6.

Yin, C. X., \& Zheng, H. (2004). Voices of Carrying Forward the Spirit of Chinese Nation. Guangming Daily, 11. 